\title{
nature
}

\section{How not to run a scientifically successful country}

Early next month, the population of Switzerland will start to vote on the abandonment of research using genetically modified animals and plants. Scientists have behaved commendably but to insufficient effect.

I is not often that a country's population deliberately commits a thriving research and industrial activity to the grave. A science base can weaken through lack of investment, as is happening in the United Kingdom. It can lose competitiveness through institutional sclerosis, as has happened in France. It can collapse almost overnight as a result of political upheaval, as has happened in what was the Soviet Union. But for a country voluntarily to remove itself from a lively scientific arena in which it is highly successful is a unique phenomenon. To do so in a fully educated and democratic way would be some sort of signal sent to the rest of the world. To do so as a result of ignorance or political accident would be a tragic folly. What has gone so wrong in Switzerland that scientists and companies, faced with such a prospect in June, are taking to the streets this week and - the luckier ones at least - making contingency plans to leave the country?

Switzerland's constitution allows its people to amend it by referendum, which they do several times a year with votes decided by simple majority, and whose results are binding. On 7 June the country will vote yes or no to a ban on the production and distribution of transgenic animals, field trials with genetically modified organisms (GMOs) of any sort, and the patenting of genetically modified animals and plants (see Nature 389, 103; 1997). If the country votes yes, new and possibly existing activities become illegal from 8 June. The start of the referendum is even more imminent, because postal voting is allowed from 10 May.

Unsurprisingly, the government is against the ban. It recognizes the huge contribution transgenic animals such as knock-out mice are making in biology, the vigour of the Swiss biology community, and the strength and economic importance of its biology-based companies. Without access to transgenic animals, key parts of the Swiss academic and industrial research and technology base will up and leave. Senior vacancies in Swiss universities already remain unfilled pending the outcome of the referendum. Almost 500 graduate students working with transgenic animals, and 80 planning field trials with GMOs, might lose their chances of a doctorate. Public funding of overseas collaborations with transgenic animals would also become illegal.

\section{Optimism}

Several months ago, the outcome of the debate appeared evenly balanced, but researchers were optimistic. Swiss industry would weigh in and help to save the day, it was said. But all the signs are that early industrial initiatives failed. Commendably, the government offered legislation, intended to defuse the referendum, that would establish a national ethical committee, increase the period of legal liability after genetic engineering to 30 years, and tighten research regulations. Only after a belated perception that industry and government had failed to make a difference, Swiss Nobel prizewinners held a press conference, describing the proposed ban as "short-sighted and senseless", while a hundred or more laboratories have held open days.

In the meantime, the opponents of such research have been active on quite a different level, using large posters and slogans ("We want healthy bread", "genes = danger"), and, in one highly publicized event, halting vessels carrying transgenic maize by river into the country. The result of all of this turns out to give grounds for pessimism. Too often comments have been heard from the public that exhibit a purely emotional reaction to the referendum with little consideration of its wider implications. "I'm for the amendment because I don't want human cloning" is one depressingly symptomatic comment. The signs from private opinion polls are that researchers have made little headway.

\section{Concerns}

It was always too simplistic (and is now futile) to argue, as some scientists have, that education is the key. The public has emotive responses that cannot be ignored. Yes, there is a gut reaction to some developments that can be allayed by familiarity. But there are other components that tap more deeply rooted concerns, engendered by culture and a sense of values associated with what animal or human existence is about. To attempt to distinguish between these components appears irrelevant, given the Green movement's success at enhancing every fear it can lay its hands on. For scientists to find themselves in a national battle against such fears is wrong in principle and a poor reflection of the Swiss way of conducting the country's affairs. Be that as it may, scientists estimate that as much as 40 per cent of the population has little idea of what the real issues are and is beyond the reach of anything scientists can do. The fact that major pharmaceutical companies are only grudgingly respected by many Swiss does not help.

In these circumstances, what can be done? The scientists have no choice but to conclude that attempts to enlighten the public have proved inadequate. Researchers are right to lower the level of debate and take to the streets, as they have done this week, waving placards, though perhaps their level ("Don't repeat the example of Galileo") is still sometimes overly cerebral. In the short time that is left, researchers must try even harder to communicate the message that their work must be allowed to continue, above all, because of its potential contribution to human health. Appeals to scientific freedom, or to the potential threat to scientists' careers, are unlikely to make much impact.

The other message to emphasize is that, where there are fears, whether or not these are considered justified by the scientific community, they can be addressed through a system of regulation and monitoring - as the government has already proposed, and other countries, such as Germany, have demonstrated.

But, above all, the current stalemate should lead the Swiss people to reconsider the appropriateness of decision-making by referendum in a highly complex world where few can have detailed knowledge of the issues at stake and their full implications. If Switzerland does vote in June to cut itself off from one of the most potentially valuable channels of modern biomedical research, the blame should be apportioned more widely than to a group of highly organized activists. 